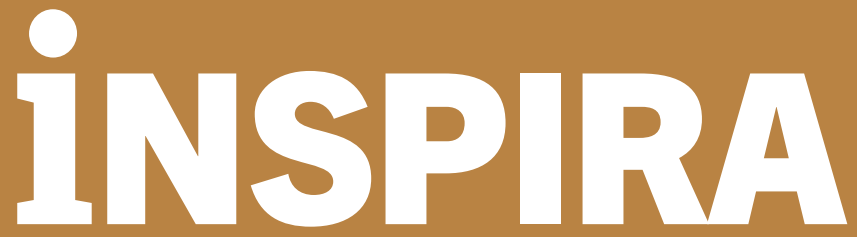

Tidsskrift for anestesi-, operasjon- og intensivsykepleiere

Forskningsartikler | Vol. 16, No. 1, 2021, s. 16-29

\title{
Pasienters opplevelser og erfaringer med regional anestesi i den perioperative fasen
}

\author{
Sigrunn Drageset \\ Anestesisykepleier, førsteamanuensis, Institutt for helse- og omsorgsvitskap, Høgskulen på Vestlandet \\ E-post: sigrunn.drageset@hvl.no
}

\section{Maren-Sofie Brakstad-Pilskog}

Anestesisykepleier, master i anestesi sykepleie, Haraldsplass Diakonale Sykehus

\section{Venke A. Johansen}

Intensivsykepleier, førsteamanuensis, Institutt for helse-og omsorgsvitskap, Høgskulen på Vestlandet, RVTS Vest (ressurssenter om vold, traumatisk stress og selvmordsforebygging region vest), Helse Bergen

\section{Astrid Karin Berland}

Anestesisykepleier, dosent, Institutt for helse- og omsorgsvitskap, Høgskulen på Vestlandet

\section{Sammendrag}

Bakgrunn: Operasjonspasienter som får regional anestesi, er ofte våkne perioperativt og møter flere profesjonsgrupper i det perioperative forløpet. Det er derfor viktig å få $\varnothing \mathrm{kt}$ innsikt i pasienters opplevelser og erfaringer.

Hensikt: Beskrive og $\varnothing$ ke forståelsen om hvordan pasienter opplever og erfarer den perioperative fasen i regional anestesi, noe som kan bidra til økt trygghet hos pasienten gjennom en enda bedre ivaretakelse.

Metode: Studien har et kvalitativ deskriptivt design og omfatter femten individuelle intervju av urologiske og ortopediske pasienter som har fått utført et kirurgisk inngrep. Intervjuene er analysert ved bruk av Malteruds systematiske tekstkondensering.

Resultat: Det var viktig å kjenne seg ivaretatt og trygg gjennom hele det perioperative forløpet. Flere opplevde det trygt å ha flere profesjonsgrupper rundt seg. I tillegg var det viktig å få detaljert

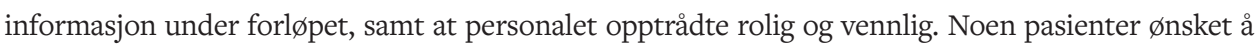
sove for å unngå å oppleve smerter og annet ubehag, mens andre ønsket å være våkne under operasjonen på grunn av et behov for å ha kontroll. Flere opplevde hjelpeløshet og at det var vanskelig å være avhengig av hjelp under og etter operasjon. I tillegg opplevde noen en krenkelse av bluferdigheten og tap av kontroll i forbindelse med intime gjøremål. Pasientene opplevde at det var utfordrende å uttrykke sine smerter på en smerteskala. Erfaringer fra tidligere operasjoner hadde betydning.

\footnotetext{
(c) 2021 Sigrunn Drageset, Maren-Sofie Brakstad-Pilskog, Venke A. Johansen \& Astrid Karin Berland. This is an Open Access article distributed under the terms of the Creative Commons Attribution 4.0 International License (http://creativecommons.org/licenses/ by/4.0/).
}

Drageset S, Brakstad-Pilskog M-S, Johansen VA, Berland AK. Pasienters opplevelser og erfaringer med regional anestesi i den perioperative fasen. Inspira. 2021;16(1):16-29. https://doi.org/10.23865/inspira.v16.3039 
Konklusjon: Det er viktig å tilpasse forholdene til den enkelte pasient slik at de får best mulig opplevelser og erfaringer. God ivaretagelse, som ved tilstrekkelig informasjon, god smertelindring og rolig opptreden, er sentralt. $\AA$ ha flere profesjonsgrupper rundt seg i den perioperative fase oppleves trygt.

Nøkkelord: operasjonspasienten; perioperativ pasientopplevelse; regional anestesi; kvalitative intervju

\section{Abstract}

\section{Patients' experiences with regional anesthesia in the perioperative phase}

Background: Surgical patients receiving regional anesthesia are often awake perioperative, and meet several healthcare professionals in the surgical pathway. This is why it is important to get insight into patients' experiences.

Purpose: The purpose of this study is to describe and increase the understanding of how patients experience the perioperative phase during regional anesthesia. This may increase patients' experience of safety, through improved care.

Methods: The study has a qualitative, descriptive design, including fifteen individual interviews of urologic and orthopedic surgical patients. The interviews were analyzed using Malteruds' systematic text condensation.

Results: It was important to feel cared for and safe during the perioperative pathway. Several of the patients felt safe due to multiple healthcare professionals being present. In addition it was important to receive detailed information continously, and that personnel acted calm and friendly. Some patients wished to sleep to avoid pain and discomfort, while others wished to be awake during surgery due to a need to be in control. Several of the patients experienced feeling helpless, and that it was difficult to be dependent of others during and after surgery. In addition, some experienced a loss of control, and a violation of their dignity in relation to intimate actions. Patients experienced that it was challenging to express their level of pain on a scale. Experiences from earlier surgeries were also important.

Conclusion: It is important to adjust the environment to individual patients, to improve their experiences. Good care, and sufficient information, good pain relief and a calm presence are central. Having several professions present in the perioperative phase feels safe.

Keywords: the surgical patient; perioperative experiences; regional anesthesia; qualitative interview

\section{Introduksjon}

Denne studien setter søkelys på pasienter i perioperativ fase som skal gjennomgå en ortopedisk eller urologisk operasjon i regional anestesi på et stort lokalsykehus. I denne sammenheng er perioperativ fase tiden før og under operasjon, og den postoperative fase etter operasjon. Regional anestesi omfatter ulike former for blokader som epidural- og spinal anestesi, og der sedasjon kan benyttes i tillegg $(1,2)$. Høyt tempo og tidvis stressfullt miljø, der flere profesjonsgrupper som anestesi- og operasjonssykepleiere, kirurger og anestesileger samarbeider i et operasjonsteam, preger en operasjonsavdeling (3).

Kirurgiske inngrep kan føre til psykologiske og fysiologiske endringer hos pasienter, blant annet relatert til type operasjon $(4,5)$. Flere studier viser at operasjonspasienter 
ofte føler på spenning, engstelse og uforutsigbarhet (5-9). Pasientens engstelse og usikkerhet kan være relatert til smerter, selve anestesien, komplikasjoner som blødning og det ukjente miljøet på operasjonsstuen (4). Tidligere forskning har konkludert med at mange pasienter som skal ha regional anestesi før operasjonen opplevde engstelse og frykt for det de skulle gjennom (9-11), noe som kan forsterke eventuell sårbarhet hos våkne pasienter som får regional anestesi (12). Dette $\varnothing$ ker behovet for informasjon og god ivaretakelse i den perioperativ fasen $(10,13)$.

Mange pasienter er i en sårbar sitasjon, og i den perioperative fasen er det viktig at de ulike profesjonsgruppene skaper tillit og etablerer trygghet $(10,14)$. Et hovedmål i den perioperative fasen er å tilrettelegge for pasientene så de føler seg trygge og godt ivaretatt (15). Både Pritchard (16) og Durling et al. (17) trekker frem at det kan være en utfordring å skape tillit og trygghet hos pasienten. Godt formidlet preoperativ informasjon som er forståelig for pasienten bidrar ofte til å dempe eller forebygge en slik engstelse, noe som også gir $\varnothing$ kt tilfredshet hos pasienter $(4,10,18)$. Walker (18) fant at preoperativ informasjon i forbindelse med innleggelse ofte kan oppleves komplisert og uforståelig for pasientene, og at dette forsterkes når de møter flere profesjonsgrupper i denne situasjonen.

Til tross for at det finnes en rekke studier som belyser operasjonspasienters engstelse i den perioperative fasen, så er det fremdeles behov for ytterligere forskning om temaet $(4,6,9,11)$. Operasjonspasientene sin erfaring med regional anestesi i perioperativ fase kan gi profesjonene $\varnothing \mathrm{kt}$ innsikt i hvordan en best mulig kan ivareta disse pasientene. Etter vår kjennskap er det ikke gjennomført tilsvarende kvalitative studier om urologiske og ortopediske pasienters individuelle opplevelser og erfaringer i forbindelse med regional anestesi i den perioperative fase i Norge.

Hensikten med studien var å bidra til økt kunnskap og forståelse om hvordan urologiske og ortopediske pasienter erfarer den perioperative fasen i regional anestesi. Denne innsikten kan bidra til økt trygghet hos pasienten gjennom en enda bedre ivaretakelse.

Følgende forskningsspørsmål belyses: «Hvordan opplever og erfarer urologiske og ortopediske pasienter som får regional anestesi den perioperative fasen?»

\section{Metode}

Studien har et kvalitativ deskriptivt forskningsdesign, med individuelle intervju som metode. Det ble brukt semistrukturerte intervju-guide, se tabell 1.

Tabell 1: Tema i intervjuguiden

Hvordan opplevde du å være operasjonspasient under ditt opphold på sykehuset?

Hvordan opplevde du møtet med operasjonsavdelingen?

Hvordan opplevde du informasjonen du fikk på operasjonsdagen?

Hvordan hadde du det rett før operasjon, under og etterpå? 


\section{Rekruttering og utvalg}

Rekrutteringen av pasienter var på et stort lokalt sykehus. En sykepleier på kirurgisk poliklinikk var behjelpelig med rekruttering av pasienter før operasjon. Kun urologiske og ortopediske pasienter var aktuelle fordi denne pasientgruppen skulle ha regional anestesi. Det ble benyttet strategisk utvelgelse av pasienter for å få en bred variasjon i utvalget. Inklusjonskriteriene var: pasienter av begge kjønn over 18 år, som skulle utføre et kirurgisk inngrep i regional anestesi, enten urologisk eller ortopedisk, gode norskkunnskaper og vurdert i tråd med ASAs (American Society of Anesthesiologists) klassifikasjonssystem innen nivå 1 eller 2 . ASA 1 eller 2 innebærer relativt friske pasienter eller med moderat organlidelse. Pasienter som ikke var klar og orientert ble ekskludert. Det ble rekruttert 21 mulige pasienter, der 6 av disse ble strøket av operasjonsprogrammet. Det totale utvalget ble 15 pasienter, 9 kvinner og 6 menn, med gjennomsnittsalder 67 år. Fem pasienter skulle få kneprotese, 7 hofteprotese og 3 skulle ha prostataoperasjoner. Tre av 15 pasienter fikk spinalbedøvelse. Ni fikk lett til moderat sedasjon under operasjon. Utvalget ble vurdert som tilfredsstillende for å kunne belyse forskningsspørsmålet.

\section{Datasamling}

Andreforfatter (M) gjennomførte intervjuene. Intervjuene ble gjennomført fra mars til mai 2017, og hadde en varighet på 30-45 min. Intervjuspørsmålene var formulert med basis i forskningsspørsmålet, tidligere forskning og erfaring. Det ble tatt hensyn til pasientene sin postoperative tilstand med tanke på tretthet og smertepåvirkning ved valg av intervjutidspunkt. Intervjuene ble utført på sykehuset. Både pasientrommet og kontor ble brukt til å gjennomføre intervjuene. Ni av de femten intervjuene ble utført på pasientrommet dersom pasienten var alene. De resterende seks ble utført på et tilgjengelig kontor, der intervjusituasjonen kunne forløpe uforstyrret.

Fire pasienter ble intervjuet på operasjonsdagen, ti stykker første postoperative dag, og en andre postoperative dag. Alle pasienter samtykket i lydopptak av samtalen. Intervjuatmosfæren og ikke-verbal kommunikasjon ble registrert.

\section{Analyse}

Intervjuene ble transkribert (av andreforfatter) før de ble gjenstand for kvalitativ analyse. Analysen foregikk ved systematisk tekstkondensering som er beskrevet i form av 4 trinn av Malterud (19). I trinn 1 ble alle intervjuene lest flere ganger for å få et helhetsinntrykk, og som ble grunnlag for formuleringer av noen foreløpige tema. Trinn 2 handler om å identifisere meningsbærende enheter. Tekstbiter i intervjumaterialet som inneholdt utsagn om foreløpige temaer fra trinn én, ble merket og samlet i grupper etter tema. Trinn 3 handler om å abstrahere innholdet $\mathrm{i}$ de enkelte meningsbærende enhetene. Dette gjennomføres ved å hente ut mening ved å kondensere innholdet i de 
meningsbærende enhetene. Her ble hvert tema analysert separat og meningsinnholdet sammenfattet (kondensert).

I fjerde og siste trinn ble alle utvalgte deler av teksten i de meningsbærende enhetene satt sammen i igjen. Dette består i å sammenfatte hvert tema og sammenhengen mellom dem til en tekst som representerer resultatene av undersøkelsen (19). Forskerteamet bestod av alle forfatterne, og alle var delaktige i analysen. For å unngå forutinntatte holdninger som kunne påvirke funnene var det viktig at forfatterne var bevisst sin forforståelse, da tre er anestesisykepleiere og en er intensivsykepleier. I tillegg har første, tredje og siste forfatter lang erfaring med forskning og med utdanning av anestesi- og intensivsykepleiere.

Tabell 2: Eksempler fra analysen: Fra meningsbærende enhet til tema om faktorer som bidrar til trygghet

\begin{tabular}{llll}
\hline Meningsbærende enhet (Trinn 1) & Koding (Trinn 2) & $\begin{array}{l}\text { Kondensert } \\
\text { meningsenhet (Trinn 3) }\end{array}$ & Tema (Trinn 4) \\
\hline $\begin{array}{l}\text { «Viktig å se situasjonen til den som } \\
\text { en møter og være til stede for } \\
\text { pasienten» }\end{array}$ & $\begin{array}{l}\text { Viktig å bli sett } \\
\text { og hørt }\end{array}$ & A bli sett og hørt & $\begin{array}{l}\text { Faktorer som } \\
\text { bidrar til trygghet }\end{array}$ \\
$\begin{array}{l}\text { «Det var egentlig bare trygt å ha et } \\
\text { helt team rundt seg, ja jeg syntes } \\
\text { det var trygt» }\end{array}$ & $\begin{array}{l}\text { Trygt å ha et helt } \\
\text { team rundt seg }\end{array}$ & Team bidrar til trygghet \\
\hline
\end{tabular}

\section{Etiske hensyn}

Studien var ikke vurdert som fremleggingspliktig av Regional etisk komite (2018/155 REK nord). Den var godkjent av NSD (Norsk senter for forskningsdata) (52264). Informantene fikk muntlig og skriftlig informasjon om studien. De ble orientert om at det var frivillig deltakelse og om muligheten til å trekke seg underveis. De fikk også informasjon om at datamaterialet skulle bli anonymisert og behandlet konfidensielt. Informantene samtykket skriftlig. I tillegg fikk de tilbud om samtale med en i operasjonsteamet dersom det var $\varnothing$ nskelig. Ingen uttrykte behov for det. Informantene gav uttrykk for at de opplevde intervjusituasjonen som god.

\section{Resultater}

Funnene ble kategorisert i fem tema som beskrev informantenes opplevelser og erfaringer i den perioperative fasen: faktorer som bidrar til trygghet; informasjon; smerter; tap av kontroll; tidligere erfaringer som operasjonspasient. To temaer hadde undertema, se tabell 3 .

Temaene som presenteres som funn i denne artikkelen representerer pasientenes opplevelser og erfaringer i den perioperative fasen tilknyttet regional anestesi. 
Tabell 3: Tema og undertema

\begin{tabular}{ll}
\hline Tema & Undertema \\
\hline Faktorer som bidrar til trygghet & Et godt førsteinntrykk \\
& $\begin{array}{l}\AA \text { ha flere profesjonsgrupper rundt seg } \\
\text { Tempo i behandlingen }\end{array}$ \\
Informasjon & $\begin{array}{l}\text { Fortløpende informasjon } \\
\text { Motstridende informasjon }\end{array}$ \\
Smerter & \\
Tap av kontroll & \\
Tidligere erfaringer som operasjonspasient & \\
\hline
\end{tabular}

\section{Faktorer som bidrar til trygghet}

I intervjuene kom det frem ulike faktorer som bidro til økt trygghet, som et godt førsteinntrykk, å ha flere profesjoner rundt seg og tempo i behandlingen.

\section{Et godt førsteinntrykk}

Et godt førsteinntrykk av operasjonsteamet var viktig for følelsen av å bli ivaretatt. Informantene satte pris på at personalet presenterte seg med navn, tittel og et håndtrykk. En informant sa: «Blide smil og ansikter er viktig». En tålmodig og vennlig tone var også av stor betydning, en sa: «Det er viktig at personalet bcerer over med meg». Videre var det flere som trakk frem at det var viktig at personalet var til stede i situasjonen:

«Viktig å se situasjonen til den som en møter og veere til stede for pasientene»

«Jeg følte meg sett og hørt fra første øyeblikk jeg kom inn på operasjonsavdelingen»

«For å føle meg trygg og ivaretatt er det viktig jeg blir både sett og hørt»

Men det var eksempel på utsagn som utrykte det motsatte:

«Sykepleierne var ikke skikkelig til stede for meg, jeg følte meg oversett»

«Sykepleierne var lite med $i$ situasjonen der de kvitret omkring og skrøt av nye hår-

frisyrer til hverandre»

\section{$\AA$ ha flere profesjonsgrupper rundt seg gav trygghet}

Opplevelsen av å forholde seg til flere profesjonsgrupper i operasjonsteamet i det perioperative forløpet hadde ikke noen særlig betydning for de fleste informantene: En sa: «Jeg tenkte; å ja her var det heldigvis mange som skal ivareta meg». Flere opplevde trygghet av å ha mange rundt seg for å bli ivaretatt:

«Det var egentlig bare trygt å ha et helt team rundt seg, ja jeg syntes det var trygt»

«Jeg opplevde det trygt og ha mange rundt meg, det var mange grønnkledde på operasjonssalen og med hvite kloer på oppvåkningen» 
Noen påpekte at det var positivt å ha kjente ansikt rundt seg, både før og etter operasjonen:

«A kjenne igjen personene var en god opplevelse»

\section{Tempo i behandlingen}

Flere informanter opplevde seg ivaretatt når handlinger ble utført i et rolig tempo i den perioperative fasen. Mens andre erfarte at de ble stresset av personalets travelhet, grunnet en hastig opptreden. En sa: «Det var litt hektisk, sånn at nå skal vi giøre sånn og sånn, men det er jo sånn det er... Jeg kunne gjerne tenkt meg at det var litt mer ro over tingene!» En annen uttalte: «På den postoperative avdelingen så var det en stresset sykepleier. Hun burde tatt det mer med ro».

\section{Informasjon}

Informantene var opptatt av informasjonen, dens omfang og hvordan den ble formidlet. Dette omhandlet både den fortløpende informasjon og motstridende informasjon.

\section{Fortløpende informasjon}

Forutsigbarhet gjennom fortløpende informasjon var betydningsfullt for de fleste i den perioperative fasen: «Jeg satte pris på å vite hvor de var hen $i$ løypen»; «Jeg føler meg ivaretatt når de informerer deg underveis, at de forklarer hvorfor de gjør det de gjør ...». Detaljert informasjon var spesielt viktig for noen: «Det er viktig at de kommer inn og forteller nå gjør vi sånn og sånn og sånn, nå blir det et stikk, nå blir det et lite ubehag, og så videre». «Jeg synes informasjon er mer viktig enn noe annet, og det gjelder sikkert for de fleste tror jeg... at vi fär greie på hva som skjer». Flere ble usikre når samme spørsmålene ble gjentatt flere ganger: «Jeg har ikke tall på hvor mange som har spurt om jeg har spist eller drukket noe $i$ dag». Det å få vite på forhånd at de samme spørsmålene ville komme flere ganger kunne hjelpe. En annen utrykte: «Det er avgjørende å få vite at jeg vil få de samme spørsmålene fordi da er jeg forberedt på det».

\section{Motstridende informasjon}

Motstridende informasjon gav grobunn for usikkerhet. Informantene uttrykte det slik:

«Informasjonen som blir gitt må veere riktig»

«Det er viktig at informasjonen vi fär ikke skurrer eller viser seg å voere feil»

En informant fortalte hun hadde fått to ulike beskjeder av sykepleierne postoperativt: «Noen sier det og noen sier det».

\section{Smerter}

Ulike former for smerteopplevelser ble beskrevet. De fleste hadde vært forberedt på en del smerter. Det å bli stukket tre ganger i ryggen før en kjente at spinalbedøvelsen hjalp 
ble beskrevet som smertefullt. Noen trodde også at det ville bli smerter per operativt. En informant sa: «Jeg trodde det skulle veere vondt, men det var ikke vondt». Flere av de ortopediske pasientene erfarte sterke postoperative smerter: «Det har voert en stri tørn!». En annen som hadde fått utført et ortopedisk inngrep uttrykte: «Jeg gruet meg også til smertene etter operasjonen. Nå er jeg smertelindret og har det bra. Men jeg har hatt mye vondt ja... mhm. Jeg trodde ikke det skulle bli så ille. Jeg sa det akkurat i sted til de jeg er på rom med at jeg kunne heller ha født ti unger $i$ stedet, ... jeg har født to!»

En av informantene uttrykte hvordan det var å beskrive smerter basert på en smerteskala: «Når jeg sier jeg har vondt så får jeg jo de der spørsmålene om hvor smertegrensene dine er fra en til ti... ja akkurat den er vanskelig, det er ikke så lett... for det første er jo smerte individuelt... og det... ja, da sier du gjerne fem sånn midt imellom, men senere sa jeg uff nå er jeg oppe $i$ sju».

\section{Kontroll}

Mange fortalte at de følte seg hjelpeløse under og etter operasjonen og at de opplevde å miste kontroll. Det var vanskelig å være avhengig av andre, fordi en helst ville klare seg selv: «Det å voere avhengig av andres hjelp er utfordrende fordi jeg føler meg så hjelpeløs».

Spesielt opplevdes spinalbedøvelsen ubehagelig, fordi en mistet kroppskontroll og hadde følelse av å være lam. En sa: «Det var ubehagelig, ikke ha kontroll på nedre del. Jeg så for meg det er et farlig område der, og at det ikke er bra å rote for mye $i$ disse nervene og bli lam fra livet og ned!». En annen erfarte det slik: «Da var det altså et legeme som hang oppover der som ikke føltes som mitt».

Noen $\varnothing$ nsket å være våken peroperativt både av nysgjerrighet og for å ha kontroll: «Jeg synes det var helt greit... det er jo i min natur det å ha så god kontroll som jeg kan ha, uten at jeg kan gjøre noe, men at du er våken og fär med deg litt av det som skjer». «Jeg ville veere våken og bevisst fordi da følte jeg jeg hadde mer kontroll». Medvirkende til økt følelse av kontroll var å få informasjon om hva som foregikk, høre musikk, pusteøvelser eller få beroligende medikament. En sa det slik: «For å slappe helt av tar jeg litt sånne puste$\emptyset v e l s e r . .$. den $\emptyset v e l s e n$ liker jeg veldig godt og ligge og kjenne bare hvordan jeg fyller magen med luft».

Andre opplevde at det var litt ubehagelig å være våken og ville helst sove: «Jeg fikk noe å sove på, for jeg hadde ingen ønske om å høre noen saging eller banking eller noe sånt.»

Flere opplevde bluferdighet i forbindelse med kateterinnleggelse og bruken av benholdere: «Jeg vil ikke vite hva de gjør med mitt midtparti nedentil, hvor mye de ser av genitalier og så videre». For andre var det ikke noe problem å være avkledd:

En sa: «Jeg tenkte altså «søren» jeg er ikke den eneste, nei, det de ser på meg har de sikkert sett før, på alle måter. Så nei, det med bluferdighet og sånn det bekymrer meg $i k k e ~ i$ det hele tatt». En annen uttrykte: «Jeg er for gammel til å bekymre meg for slikt.» Noen informanter uttrykte at det å trenge hjelp til toalettbes $\varnothing \mathrm{k}$ etter operasjon og ikke ha kontroll selv ble opplevd som nedverdigende: «Det var litt nedverdigende på en måte». 
Det ble også presisert at det hjalp når sykepleier normaliserte situasjonen ved å si at dette var jobben deres og noe de gjør hver dag.

\section{Tidligere erfaringer som operasjonspasient}

Informantene fortalte om ulike erfaringer fra tidligere sykehusopphold. Mange av dem var mer spent enn engstelig. Erfaringer fra tidligere sykehusopphold hadde en positiv betydning, på en slik måte at de som hadde gjennomført en operasjon tidligere var mindre usikre: «Første gang jeg var operert var jeg litt mer spent, denne gangen visste jeg hva jeg gikk til for å si det sånn». En annen utrykte: «Det der med masse blod og sånn det har aldri gjort meg noen ting, fordi jeg har blitt operert før». De som allerede hadde positive operasjonserfaringer fra tidligere operasjoner så frem til å få hjelp til å bedre helsen sin, slik at de kunne gjenoppta hobbyer og bli aktive igjen.

Noen informanter hadde andre erfaringer: «Sist jeg skulle opereres så sa anestesilegen; 'ja det var høgre hofte', da sa jeg nei, nå må du gi deg, det er ikke høgre hofte, men høgre kne». En av informantene gruet seg til spinalbedøvelsen, fordi forrige gang hadde anestesilegen spøkt og sagt: «Jammen hadde vi flaksen denne gangen også». Pasienten fortalte at han var med på spøken den gangen, men nå i tilsvarende situasjon husket han kommentaren: «Tenk om de ikke har flaks denne gangen».

\section{Diskusjon}

Studiens hensikt var å innhente kunnskap om hvordan urologiske og ortopediske pasienter opplevde og erfarte regional anestesi i den perioperative fasen.

Funnene viste hvordan ivaretakelse opplevdes på forskjellige måter. Trygghetsfølelse ble av informantene beskrevet som et godt førsteinntrykk, å ha flere profesjonsgrupper rundt seg og at handlinger ble utført i et rolig tempo. Våre funn om at førsteinntrykket av personalet er viktig er i tråd med tidligere forskning der et godt førsteinntrykk beskrives som betydningsfullt for sykehusoppholdet (10). Det at våre informanter trakk frem betydningen av at personalet var rolig og til stede i situasjonen støttes også av studien til Karlsson et al. (12). Andre studier med tilsvarende funn viser at handlinger og væremåte har stor betydning for trygghet hos pasientene (10,12,20-22). Ifølge Segesten (23) Ønsker pasienter å bli møtt med vennlighet, rolig opptreden, at en bryr seg om dem og at helsepersonell inngir tillit i møte med pasienten.

Vi fant at informantene opplevde det trygt og følte seg ivaretatt når det var flere rundt dem, dette i motsetning til Hughes (24), som på bakgrunn av en litteraturstudie konkluderte med at pasienter kan oppleve å bli forvirret av at flere ulike faggrupper er til stede. Segesten (23) påpeker at det viktig for pasienten å kunne ha tillit til at man kan få hjelp og behandling av kvalifiserte hjelpere, som eksperter og helsepersonell med høy kompetanse. Det å stole på at hjelpen er tilgjengelig sammen med rett behandling er avgjørende for trygghetsfølelsen.

Funnene viste blant annet at fortløpende, forklarende og hensiktsmessig informasjon har stor betydning for pasientens opplevelse av forutsigbarhet og kontroll i det 
perioperative forløpet. Våre funn er her i samsvar med andre som viser at god informasjon gjennom forløpet har betydning for å forebygge og dempe angst, noe som gir $\varnothing \mathrm{kt}$ grad av tilfredshet hos pasientene $(3,4,8,18,25,26)$. Et viktig moment som kan redusere forutsigbarheten og kontrollen er at pasienten ikke forstår informasjonen som blir gitt. Dette aspektet framtrer tydelig i grunnlagsdokumentet for anestesisykepleiere (27), der det påpekes at anestesisykepleieren i samarbeid med de andre i operasjonsteamet skal gi pasienten tilstrekkelig og forståelig informasjon. Preoperativt er det viktig at pasienten får informasjon om hele operasjonsforløpet i tillegg til mulighet til å komme med spørsmål. Det som oppleves som rutinearbeid for de profesjonelle kan for pasientene bli en skremmende opplevelse $(3,10)$. Haugen et al. (8) trekker fram at pasienter som gjennomgår et kirurgisk inngrep i regionalbed øvelse trenger fortløpende informasjon om hva som kommer til å skje, og hvorfor. Walker (18) har blant annet funnet at den preoperative informasjonen ofte kan bli komplisert, og at dette kan forhindre at pasienten forstår det som blir sagt. Tilsvarende påpeker Segesten (23) at pasienter ønsker en informasjon av sykepleierne som er forståelig, som gir forutsigbarhet, og som de kan nyttiggjøre seg. Pasienter er mer tilfredse når de er godt informerte på forhånd, slik at de erfarer opplæring og støtte $(10,28)$.

Kirurgisk virksomhet er ofte forbundet med et høyt tempo der mye skal skje på kort tid, noe som forårsaker at pliktig informasjonsformidling til tider kan foregå kjapt $(3,27)$. Det er likevel viktig med en balansegang, slik at pasientene ikke overøses med for stor mengde informasjon på en gang (29). I tillegg må formidling av informasjon vurderes individuelt og tilpasses den spesifikke situasjonen (30). Svært engstelige pasienter kan for eksempel kanskje ha større behov for nærhet og oppmerksomhet enn andre. Våre funn viste også at motstridende informasjon førte til økt usikkerhet hos noen pasienter, noe som er i tråd med Segesten (23), som påpeker at informasjonen fra helsepersonell må gis på en slik måte at den ikke bidrar til økt usikkerhet og utrygghet.

Våre informanter erfarte ulik grad av smerter. Noen kjente smerter operasjonsdagen når de fikk spinalbedøvelse, mens andre erfarte sterkere grad av smerter første postoperative dag. Det viser seg at postoperative smerter fremdeles blir underbehandlet til tross for mye forskning på området (31-33). I en review fant Wooldridge og Branney (31) at sykepleiere ofte undervurderer pasientenes smertenivå. Årsak til dette kan skyldes mangelfull kommunikasjon og klinisk vurdering av pasientens smertetilstand $(34,35)$ noe som kan resultere i utilstrekkelig og dårlig smertelindring (35).

Noen av informantene opplevde det utfordrende å uttrykke sine smerter etter en smerteskala. Smerteopplevelsen er subjektiv og smerteterskelen er variert $(33,36)$, noe som gjør det problematisk å plassere smerteintensitet på en skala. Likevel er det ofte viktig å benytte måleverktøy som en slik smerteskala representerer. Det at pasientene kan gi uttrykk for sine smerter ved hjelp av en skala kan gi pasienten selv og oss et bilde av smerteintensiteten, i tillegg til å være anvendelig for å forstå om smertene $\varnothing$ ker eller blir lettere (10). Det er viktig å huske at oppmerksomhet og forståelse for den enkeltes behov i tillegg til god smertelindring kan bedre situasjonen, og bidra til at smerten takles bedre $(10,34,37,38)$. 
Flere av våre informanter opplevde hjelpeløshet og at det var vanskelig å være avhengig av hjelp under og etter operasjon. Våre funn er i overensstemmelse med Rosen et al. (20) som trekker frem at tap av kontroll kan medføre eller forsterke hjelpeløshet. Pasientrollen er utfordrende og medfører ofte en opplevelse av hjelpeløshet $(20,21)$. Følelsen av å miste kontroll oppstår når en selv ikke kan styre det som skjer (3). Pasientens opplevelse av å ha kontroll og behov for kontroll varierer $(12,30)$. Videre fant vi at våre informanter hadde ulike behov, for eksempel ønsket noen å ha kontroll ved å være våken peroperativt der det var behov for fortløpende informasjon. Videre fant vi at noen fikk bedret sin opplevelse av kontroll og indre ro gjennom tiltak som musikk eller puste$\varnothing$ velser, i tillegg til informasjon og eventuelle beroligende medikamenter. Betydningen av faktorer som informasjon og musikk er vurdert som spesielt viktige for pasienter i regional anestesi som har mistet evnen til å kontrollere eller gjenkjenne deler av kroppen $(10,39,40)$. Mens andre av våre informanter derimot $\varnothing$ nsket å ha nok kontroll til å kunne velge å sove for å unngå smerter og ubehag. En relevant fortolkning er at de var trygge nok i situasjonen med så høy grad av tillit at de kunne gi fra seg kontrollen til de profesjonelle i teamet.

Noen av våre informanter opplevde krenkelse av bluferdigheten og tap av kontroll $\mathrm{i}$ forbindelse med intime gjøremål. Ifølge Martinsen (41) er det fare for å krenke pasienter sin integritet og verdighet hvis en overskrider den andres urørlighetssone. Imidlertid fant vi at informantene ble beroliget når sykepleier normaliserte situasjonen ved intime gjøremål. Dette kan sees i lys av personorientert profesjonalitet. Man ser på pasientene med «et hjertelig deltakende øye» (41,42). På denne måten engasjerer en seg i pasientene og i deres situasjon. En viser interesse for pasientene som hele personer samtidig som en bruker sin fagkunnskap på en utforskende og vurderende måte, for at situasjonen kan bli så positiv som mulig for pasientene. Gjennom en slik holdning kan en gjøre pasientene tryggere (42).

I hovedsak fant vi at erfaringer fra tidligere gjennomførte operasjoner medførte mindre usikkerhet. Likevel preget både positive og negative erfaringer fra tidligere operasjoner forventningene de bar med seg i forhold til operasjonen de nå skulle ha. Dette er i tråd med annen forskning som viser at tidligere positive operasjonserfaringer kan bidra til $\varnothing \mathrm{kt}$ trygghet $(10,21)$, mens negative erfaringer kan bidra til engstelse og utrygghet (4). For å unngå unødig engstelse trenger pasientene profesjonelle i teamet som er empatiske og oppmerksom me på pasientens behov både i den pre-, per- og postoperative fasen $(27,43)$.

\section{Metodiske betraktninger}

En styrke ved studien er at det er gjennomført individuelle intervju av pasienter kort tid etter operasjonen. Det bidrar til bedre hukommelse hos informantene i intervjusituasjonen, enn om intervjutidspunktet hadde vært lang tid etter operasjonen.

I kvalitativ forskning er det ifølge Malterud (19) en fordel med erfaring, kunnskap og kjennskap til konteksten. Det ble vektlagt at spørsmålene i intervjuene var åpne, for å rette oppmerksomheten mot hva det var ønskelig at informantene skulle snakke om, men samtidig kan spørsmålene ha påvirket svarene fra informantene. 
Det kan være en styrke at andreforfatter, som utførte intervjuene, arbeider som anestesisykepleier. Imidlertid kan forfatterne sin forforståelse som anestesisykepleiere og intensivsykepleier, og forskning på egen arbeidsplass, ha påvirket funnene. Ifølge Malterud (19) er det viktig at en er oppmerksom på sin egen forforståelse under hele forskningsprosessen. I løpet av analysen har vi vært oppmerksomme på egen tolkning og forforståelse, at deltakers stemme uttrykkes i sitatene, som i lag med relevant teori var grunnlag for endelig fortolkning.

Alle forfatterne bidro til utforming av temaer. Både datainnsamlingen og analysen er utført i nært samarbeid og enighet mellom alle forfatterne som har lest den transkriberte teksten flere ganger. Studien presenterer også direkte sitater fra informantene. Videre har samarbeidet mellom forfatterne bidratt til å styrke funnenes pålitelighet, gyldighet og troverdighet. Beskrivelse av metode og utvalg, samt beskrivelse av funn med sitat sikrer studiens transparens.

Studiens overførbarhet, om funnene kan anvendes i andre sammenhenger, er forsterket gjennom beskrivelse av kontekst, datainnsamling, analyse og funn. Imidlertid kan ikke funn fra denne studien overføres til alle pasienter i perioperativ fase som får regional anestesi, men kan bidra til bedre forståelse for pasientene sin situasjon.

\section{Konklusjon}

Studien beskriver ulike opplevelser og erfaringer hos pasientene gjennom den perioperative fasen i regional anestesi. Det er viktig å tilpasse forholdene til den enkelte pasient slik at de får best mulig opplevelser og erfaringer. En god ivaretagelse er avhengig av en rekke faktorer, som god fortløpende og tilstrekkelig informasjon, god smertelindring og rolig opptreden. Det oppleves trygt å bli ivaretatt av flere profesjonsgrupper i den perioperative fasen.

\section{Implikasjoner for praksis og videre forskning}

God informasjon om hva skal skje er viktig for å kunne gi pasientene god forutsigbarhet. I tillegg er det også viktig at profesjonsgruppene inngir tillit og trygghet i møte med pasientene. Uavhengig av tidligere opplevelser og erfaringer hos pasientene er det viktig å gi pasientene en best mulig opplevelse i den perioperative periode.

Vi foreslår etnografisk observasjonsstudie i tillegg til fokusgruppeintervju blant anestesi-, operasjons- og intensivsykepleiere for å belyse hvordan pasientene blir best mulig ivaretatt av de tre profesjonene i den perioperative fasen.

\section{Takksigelse}

Takk til alle deltakerne i denne studien som delte sine erfaringer med oss.

\section{Kilder}

1. Bjørnestad IC, Halstensen T-D. Peroperativ sykepleie. I: Leonardsen A-C, redaktør. Anestesisykepleie. 3. utg. Oslo: Cappelen Damm; 2021. s. 257-67. 
2. Norsk legemiddelhåndbok. T22.3.1 Lokal- og regionalanestesi. 2020. Norsk legemiddelhåndbok [elektronisk bok]. Tilgjengelig fra: https://www.legemiddelhandboka.no/T22.3.1/Lokal\%E2\%80\%91_ og_regionalanestesi

3. Valeberg BT. Operasjonspasienten. I: Leonardsen A-C, red. Anestesisykepleie. 3. utg. Oslo: Cappelen Damm; 2021. s. 239-45.

4. Sigdel S. Perioperative anxiety: A short review. Glob Anesth Perioper Med. 2015;1(4):107-8. https://doi.org/10.15761/GAPM.1000126

5. Jiwanmall M, Jiwanmall SA, Williams A, Kamakshi S, Sugirtharaj L, et al. Preoperative anxiety in adult patients undergoing day care surgery: Prevalence and Associated factors. Indian J Psychol Med. 2020;42(1):87-92. https://doi.org/10.4103/IJPSYM.IJPSYM_180_19

6. Svensson M, Nilsson U, Svantesson M. Patients' experience of mood while waiting for day surgery. J Clin Nurs. 2016;25(17-18):2600-8. https://doi.org/10.1111/jocn.13304

7. Alacadag M, Cilingir D. Presurgery anxiety and day surgery patients' need for information J Perianesth Nurs. 2018;33:658-68.

8. Haugen AS, Eide GE, Olsen MV, Haukeland B, Remme AR, et al. Anxiety in the operating theatre: A study of frequency and environmental impact in patients having local, plexus or regional anaesthesia. J Clin Nurs. 2009;18(16):2301-10. https://doi.org/10.1111/j.1365-2702.2009.02792.x

9. Yilmaz E, Togac HK, Cetinkaya A, Togac S. A qualitative study of the operating room experience of patients who underwent surgery under spinal anesthesia: "It was like an adventure". Nurs Health Sci. 2020;22(3):648-57. https://doi.org/10.1111/nhs.12708

10. Bergman M, Stenudd M, Engstrøm A. The experience of being awake during orthopaedic surgery under regional anaesthesia. Int J Orthop Trauma Nurs 2012;16:88-96.

11. Bager L, Konradsen H, Dreyer PS. The patient's experience of temporary paralysis from spinal anaesthesia, a part of total knee replacement. J Clin Nurs. 2015;24(23-24):3503-10. https://doi.org/ 10.1111/jocn.13007

12. Karlsson AC, Ekebergh M, Larsson M, A, Almerud O, S. Only a whisper away. A philosopical view of the awake patient's situation during regional anaesthetics and surgery. Nurs Philos. 2012;13(4):257-65. https://doi.org/10.1111/j.1466-769X.2012.00538.x

13. Sundquist A, Nilsson U, Holmefur M, Anderzen-Carlsson A. Promoting person-centred care in the perioperative setting through patient advocacy: An observational study. J Clin Nurs. 2018;27:2403-15. https://doi.org/10.1111/jocn. 14181

14. Clair C, Engstrom A, Stromback U. Strategies to relieve patients' preoperative anxiety before anesthesia: Experiences of nurse anesthetists. J Perianesth Nurs. 2020;35(3):314-20. https://doi.org/ 10.1016/j.jopan.2019.10.008

15. Marley RA, Sheets S. Preoperative evaluation and preparation of the patient. I: Nagelhout JJ, Plaus LK, red. Nurse Anesth. St.Louis, Missouri: Saunders Elsevier; 2017. s. 311-45.

16. Pritchard M. Measuring anxiety in surgical patients using a visual analogue scale. Nurs Stand. 2010;25(11):40-4. https://doi.org/10.7748/ns2010.11.25.11.40.c8104

17. Durling M, Milne D, Hutton N, Ryan S. Decreasing patients preoperative anxiety: A literature review Aust Nurs J. 2007;14(11).

18. Walker J. What is the effect of preoperative information on patient satisfaction? Br J Nurs. 2007;1: 27-32.

19. Malterud K. Kvalitative forskningsmetoder for medisin og helsefag. 4. utg. Oslo: Universitetsforlaget; 2017.

20. Rosen S, Svensson M, Nilsson U. Calm or not calm: The question of anxiety in the perianesthesia patient. J Perianesth Nurs. 2008;23(4):237-46. https://doi.org/10.1016/j.jopan.2008.05.002 
21. Bjerring NT, Dreyer P, Edith M. Anaesthesiological nursing care- perception of general anaesthesia inoutpatients undergoing cancer diagnostics. Nordisk Sygepleieforskning. 2017;1:63-75.

https://doi.org/1018261

22. Karaca A, Durna Z. Patient satisfaction with the quality of nursing care. Nurs Open. 2019;6(2):535-45. https://doi.org/10.1002/nop2.237

23. Segesten K. Patienters upplevelser av trygghet och otrygghet. Göteborg: Segesten Förlag; 1994.

24. Hughes S. The effects of giving patients pre-operative information. Nurs Stand. 2002;16(28):33-7. https://doi.org/10.7748/ns2002.03.16.28.33.c3173

25. Brij M, Rajan K, Joginder PA, Veena C, Neeru B. Anesthesiologist's role in relieving patient's anxiety. Anesthesia essays and researches. 2017;11:449-52. https://doi.org/10.4103/0259-1162.194576

26. McDonald S, Page MJ, Beringer K, Waiak J, Sprowson A. Preoperative education for hip or knee replacement. Cochrane Database Syst Rev. 2014;13;2014(5). https://doi.org/10.1002/14651858. CDo03526.pub3

27. International Federation of Nurse A. Grunnlagsdokument for anestesisykepleiere. Oslo: Anestesisykepleierne NSF; 2016.

28. Rhodes L, Miles G, Pearson A. Patient subjective experience and satisfaction during the perioperative period in the day surgery setting: A systematic review. Int J Nurs Pract. 2006;12:178-92.

29. Aust H, Rusch D, Schuster M, Sturm T, Brehm F, et al. Coping strategies in anxious surgical patients. BMC Health Serv Res. 2016;16. https://doi.org/10.1186/s12913-016-1492-5

30. Mitchell M. A patient-centered approach to day surgery nursing. Nurs Stand. 2010;44:1059-71.

31. Wooldridge S, Branney J. Congruence between nurses' and patients' assessment of postoperative pain: a literature review. Br J Nurs. 2020;29(4). https://doi.org/10.12968/bjon.2020.29.4.212

32. Nilsson U, Jaensson M, Dahlberg K, Hugelius K. Postoperative recovery after general and regional anesthesia in patients undergoing day surgery: A mixed methods study. J Perianesth Nurs. 2019;34(3):517-28. https://doi.org/10.1016/j.jopan.2018.08.003

33. Krupic F, Grbic K, Biscevic M, Jasarevic M, Custovic S, et al. The experience of nurse anaesthetists in assessing postoperative pain in orthopaedic patients. Med Glas (Zenica). 2019;16(2). https://doi. org/10.17392/1002-19

34. Dihle A, Bjølseth G, Helseth S. The gap between saying and doing in postoperative pain management. J Clin Nurs. 2006;4:469-79.

35. Chatchumni M, Namvongprom A, Eriksson H, Mazaheri M. Exploring the different management structures in nurses responses and treating of patients' postoperative pain: A qualitative triangulation study. BMC Anesthesiol. 2019 11(2):7536-43.

36. Girdhari S, Smith SK. Assisting older adults with orthopaedic outpatient acute-pain management. Orthop Nurs. 2006;25(3):188-95; quiz 96-7. https://doi.org/10.1097/00006416-200605000-00006

37. Stubberud DG, Grønseth R. Sykepleie ved smerter. I: Almås H, red. Klinisk sykepleie: Bind I. Oslo: Gyldendal akademisk; 2016.

38. Harris K, Softeland E, Moi AL, Harthug S, Storesund A, et al. Patients' and healthcare workers' recommendations for a surgical patient safety checklist - a qualitative study. BMC Health Serv Res. 2020;2O(1):43. https://doi.org/10.1186/s12913-020-4888-1

39. Karlsson AC, Ekebergh M, Moulon A, Almerud Østerberg S. “Is that my leg?” Patients' experiences of being awake during regional anesthesia and surgery. J Perianesth Nurs. 2012;27(3):155-64. https://doi.org/10.1016/j.jopan.2012.02.005

40. Kukreja P, Talbott K, MacBeth L, Ghanem E, Sturdivant A, et al. Effects of music therapy during total knee arthroplasty under spinal anesthesia: A prospective randomized controlled study. Cureus. 2020;12. https://doi.org/10.7759/cureus.7396

41. Martinsen K. Samtalen, skjønnet og evidensen. Oslo: Akribe; 2005.

42. Martinsen K. Øyet og kallet. Berg: Fagbokforlaget; 2000.

43. Nordtvedt P. Etiske utfordringer. I: Leonardsen A-C, red. Anestesisykepleie. 3. utg. Oslo: Cappelen Damm; 2021. s. 44-54. 